\title{
THE CAREER OF THE EGYPTIAN HIGH PRIEST BAKENKHONS
}

\author{
KARL JANSEN-WINKELN, Freie Universität, Berlin
}

\section{$\mathrm{T}_{\mathrm{HE}}$ well-known block statue of the high priest Bakenkhons in Munich} (GL.WAF 38) contains a passage in which he addresses future generations and gives a detailed account of the offices he held "since he was born," with exact indications of how long he held each office. ${ }^{1}$ This passage has always been one of the favorite subjects of Egyptologists and has often been discussed. ${ }^{2}$ It is one of the rare cases which gives us solid information about the career of an Egyptian priest. But it has been used for chronological calculations as well, especially for determining the exact duration of the reign of Sethos I. ${ }^{3}$ My view differs from what is generally believed concerning the career of Bakenkhons in one point, but one which is important in several respects.

The precise information which Bakenkhons provides has already caused numerous calculations of his age at the time the statue was made and the text composed. ${ }^{4}$ From the inscription on the base, in which he asks for a "beautiful lifetime" after 110 years (of life), ${ }^{5}$ scholars have generally concluded that Bakenkhons was still alive when the statue was erected or at least when its text was drafted. ${ }^{6}$ This is not necessarily the case: asking for a "beautiful lifetime" after 110 years, the speaker can only be Bakenkhons as the statue, who wishes to endure after death. But a statue could hardly say "after my lifetime" or something similar. "After 110 years" might therefore simply mean "after the death of the owner of the statue," no matter whether he was dead or alive at the time when it was written.

${ }^{1} \mathrm{~K}$. A. Kitchen, Ramesside Inscriptions (hereafter KRI) (Oxford, 1968), vol. 3, p. 298, 11. 2-7.

${ }^{2}$ See, for example, J. H. Breasted, Ancient Records of Egypt (Chicago, 1906), vol. 3, \$§561-62; G. Lefebvre, Histoire des grands prêtres d'Amon de Karnak jusqu'à la XXI dynastie (Paris, 1929), pp. 13236; idem, "Sur l'âge du grand prêtre d'Amon Bakenkhonsou," Revue de l'Egypte ancienne 1 (1927): 13843; R. Engelbach, "Two Monuments of the Chief Prophet of Amun, Bekenkhons, with Some Remarks of Other Monuments Similarly Inscribed," Annales du Service des Antiquités de l'Egypte (ASAE) 40 (1940): 515-16; M. Plantikow-Münster, "Die Inschrift des B3k-n-bnsw in München," ZÄS 95 (1968): 127 (t); M. L. Bierbrier, "The Length of the Reign of Sethos I," JEA 58 (1972): 303; E. F. Wente and Charles C. Van Siclen III, "A Chronology of the New Kingdom," in Studies in Honor of George R. Hughes, SAOC 39

[JNES 52 no. 2 (1993)]

(C) 1993 by The University of Chicago.

All rights reserved.

0022-2968/93/5202-0003\$1.00
(Chicago, 1976), pp. 232-33; W. J. Murnane, Ancient Egyptian Coregencies, SAOC 40 (Chicago, 1977), pp. 86-87; Kitchen, review of Murnane, JNES 39 (1980): 170; H. Kees, Das Priestertum im ägyptischen Staat vom Neuen Reich bis zur Spätzeit, Probleme der Ägyptologie, vol. 1 (Leiden and Cologne, 1953), pp. 117-18; K. C. Seele, The Tomb of Tjanefer at Thebes, OIP 86 (Chicago, 1959), p. 7, n. 54; Bierbrier, The Late New Kingdom in Egypt (c. $1300 \sim 664$ B.C.): A Genealogical and Chronological Investigation (Warminster, 1975), p. 3; S. Schoske, "Historisches Bewusstsein in der ägyptischen Kunst, Beobachtungen an der Münchner Statue des Bekenchons," Münchner Jahrbuch der bildenden Kunst, Dritte Folge, Band 38 (Munich, 1987), pp. 7-8.

Bierbrier, "Reign of Sethos I," p. 303; Kitchen, review of Murnane, Ancient Egyptian Coregencies, p. 170 .

${ }^{4}$ See n. 2 above.

${ }^{5}$ KRI, vol. 3, p. 299, 1. 5.

${ }^{6}$ See Lefebvre, Histoire des grands prêtres, p. 134; idem, "Sur l'âge du grand prêtre," p. 143; Bierbrier, "Reign of Sethos I," p. 303; idem, Late New Kingdom, p. xv. 
There is some disagreement about the time when Bakenkhons went to school, the first period of his life mentioned in the biography. ${ }^{7} \mathrm{G}$. Lefebvre ${ }^{8}$ and most other commentators $^{9}$ quite rightly assume that Bakenkhons was at least five years old when he entered school, ${ }^{10}$ but recently S. Schoske ${ }^{11}$ has taken up the old idea of F. J. Chabas ${ }^{12}$ and R. Engelbach $^{13}$ that the phrase $n \underline{d} s$ jqr did not refer to Bakenkhons's school days but, rather, to his early childhood, i.e., the years from birth to the age of four. This is substantiated by the immediately preceding passage: "I will let you know my character when I was upon the earth in every office I held since I was born." ${ }^{14}$ But mentioning all the offices he held after his birth, of course, does not mean that he held any immediately after his birth-as Schoske seems to believe. It simply means that he indicated every post he held no matter how long ago this may have been. The idea that he attended school during his first four years, i.e., as a baby, is absurd. One has to add at least five or six years to the early childhood years enumerated by Bakenkhons.

The subsequent enumeration of the steps of Bakenkhons's career, eleven years as $h r j-$ jh $n$ shpr $n$ njswt $M n$ - $\left[m 3^{C} t-\right] R^{c}$ and seventy years as priest in different functions has been used by scholars to arrive at chronological conclusions. M. L. Bierbrier, ${ }^{15}$ for example, has pointed out the following: the statue bears the cartouches of Ramses II. Since Bakenkhons served in the stables of Sethos I at the beginning of his career, the statue can only have been erected towards the end of the reign of Ramses II, presumably in the last year or the year before (sixty-six). In that case, he would have been a priest under Ramses II for sixty-six years and for four additional years under Sethos I. Having served as $h r j-j h$ under Sethos I for eleven years before he became a priest, Bakenkhons's career would indicate a minimal reign of fifteen years for Sethos I (although only eleven years are actually attested).

The objections raised by W. Murnane ${ }^{16}$ against Bierbrier's calculation have been convincingly rejected by K. A. Kitchen. ${ }^{17}$ As a result, the fifteen years given for Sethos I should, in fact, be the minimum: Bakenkhons's career would fit into the reigns of Sethos and Ramses II by a narrow margin.

Examined more closely, this conclusion is not convincing, however. As for Bakenkhons's priestly career, it is clear that these years $\left(w^{c} b\right.$ : four; jtj-ntr: twelve; third

${ }^{7}$ KRI, vol. 3, p. 298, 1. 3: jrjj.j jfdt rnpt $m$ nd $\underline{d} s$ jqr.

${ }^{8}$ Lefebvre, "Sur l'âge du grand prêtre," p. 142.

${ }^{9}$ See Bierbrier, Late New Kingdom, p. 3; Seele, Tomb of Tjanefer, p. 7, n. 54.

${ }^{10}$ See also H. Brunner, Altägyptische Erziehung (Wiesbaden, 1957), p. 40. In his review of M. A. Korostovtsev, Pistsy Drevnevo Egipta [The scribes of ancient Egypt] (Moscow, 1962), in Revue d'Egyptologie (RdE) 19 (1967): 190, D. Meeks reported Korostovtsev's idea that an Egyptian boy did not attend school until he was ten years old, the Egyptian writing system being too difficult to be learned by younger children. Korostovtsev sees his theory backed by the fact that in certain school texts pupils are warned against behavior not expected of little children. I am grateful to an anonymous JNES referee for this reference. A passage in a recently published biographical inscription of the New Kingdom may confirm Koros- tovtsev's view: "[Ich verbrachte meine Kindheit (o.ä.) von] 10 Jahren, indem ich ein Kind auf dem Arm meines Vaters war. Zum Schreiber ausgebildet wurde ich danach, als ich verständig geworden war." See J. Osing, Das Grab des Nefersecheru in Zawyet Sulțan, Deutsches Archäologisches Institut, Abt. Kairo, Archäologische Veröffentlichungen 88 (Mainz am Rhein, 1992), p. 46.

${ }^{11}$ See Schoske, "Historisches Bewusstsein in der ägyptischen Kunst,” p. 25, n. 10.

${ }^{12}$ See Lefebvre, "Sur l'âge du grand prêtre," p. 142.

${ }^{13}$ Engelbach, "Two Monuments," p. 515.

${ }^{14} \mathrm{KRI}$, vol. 3, p. 298 , ll. 2-3.

${ }^{15}$ Bierbrier, "Reign of Sethos I," p. 303.

${ }^{16}$ Murnane, Ancient Egyptian Coregencies, pp. 86-87.

${ }^{17}$ Kitchen, review of Murnane, Ancient Egyptian Coregencies, p. 170. 
prophet: fifteen; second prophet: twelve; first prophet: twenty-seven) can only be added up (= seventy). But this does not necessarily hold true for the eleven years he spent as a $h r j-j h$. On the contrary, it seems to me much more probable that the first years of his priestly career are parallel to the period when he was a "cadet." To support this, we have the following information.

1. On his second statue, Cairo CG 42155 , Bakenkhons says: $:^{18}$ prj.n.j $m$ jz $n z \underline{h} 3 w m$ n $\underline{d} s$

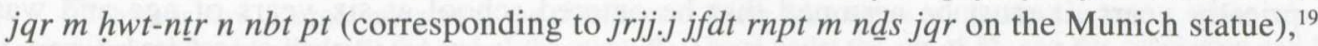
immediately followed by $s b 3 . j r w^{c} b m$ pr Jmn $m z 3 \underline{h} r \underline{d} r t j t j . j$. It thus seems that his career as a $w^{c} b$-priest started directly after he had finished his education in the $j z n z \underline{h} 3 w$ or at least without a major interruption. Of course, it is possible that there was a little break, perhaps one to two years, between the end of his schooling and his introduction to office, during which he was especially instructed in his priestly duties $\left(s b 3 . j r w^{c} b\right)$.

2. There are also some other indications (from different periods) that it was usual-or at least possible - to become a $w^{c} b$-priest when one was very young.

(a) Leiden V4 (MK): ${ }^{20}$ jrj.n.j j3wt jw.j $m n h(n) t w^{c} b . n . j$ r tr.j $n$ s33, "I was (already) in office when I was a child, I became priest at my time of discernment." Cf. Sethe's comment on the passage. In connection with $j w . j m n h(n) t$, the phrase $r \operatorname{tr} . j n s 33$ can only mean immediately following his schooling.

(b) The high priest Rm-rj, Bakenkhons's successor, says of himself: ${ }^{21}$ hpr.n.j $m$ hwn $m$ $p r-J m n$ jw.j $m w^{\complement} b$ jqr, "I became a $h w n$ in the house of Amun while I was a capable $w^{c} b$-priest." That goes with Bakenkhons's Munich inscription where the transition to the state of hwn immediately follows his education. He was a schoolboy for four years as $n \underline{d} s$ jqr, thereafter a "cadet" for eleven years as hwn. Bakenkhons could thus, like Rm-rj, have been $w^{c} b$-priest while he was a $h w n$.

(c) On the stela Louvre C 219, we have $\check{s}^{c}$. n.f rmn ntr pn (= service as $w^{c} b$-priest) jw.f $m$

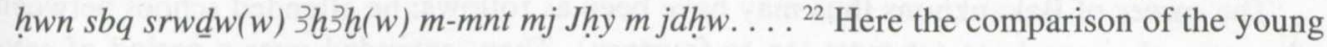
priest with the divine child Jhy is noteworthy.

(d) Stela Cairo JE 71902, 1. 4:23 jrjj.j $w^{\complement} b \underline{h} r \underline{d} r t j t j . j \ldots$.

(e) Statue Cairo CG 42230, right, 1. 2: ${ }^{24}{ }^{c} q . k w j$ ḥr nțr $m$ ḥwn jqr....

3. The possibility that Bakenkhons was at the same time $w^{c} b$-priest and $h r j$-jh is further strengthened by the fact that lower priests, at least the classes of $w^{c} b$ and $j t j-n t r$ (thereafter Bakenkhons immediately became, as third prophet, one of the highest priests of the "house of Amun"), did not have a "full-time job." 25

${ }^{18}$ Back, 1l. 1-2 = KRI, vol. 3, p. 296, 11. 1-2.

19 KRI, vol. 3, p. 298, 1. 3 .

20 Sethe, Ägyptische Lesestücke zum Gebrauch im akademischen Unterricht, Texte des Mittleren Reiches (Leipzig, 1924), p. 72, 11. 12-13.

${ }^{21}$ Cairo CG 42186, right, 1. $1=\mathrm{KRI}$, vol. 4 , p. 209 , 1. 3 .

22 KRI, vol. 4 , p. 297 , $11.6-7$.

${ }^{23}$ See A. O. A. Abdallah, "An Unusual Private Stela of the Twenty-first Dynasty from Coptos," JEA 70 (1984): $65-72$, here p. 70.
${ }^{24}$ See my Ägyptische Biographien der 22. und 23. Dynastie, Ägypten und Altes Testament 8 (Wiesbaden, 1985), p. 532.

${ }^{25}$ Helck even wants to classify only the function of the high priest as "full-time" and not that of the third or the second prophet. The career of Bakenkhons, who insists on having named all his offices, indicates that at least the second and third prophets were "professionals" too. See idem, Grammata Demotica (Festschrift Lüddeckens) (Würzburg, 1984), pp. $71-72$. 
4. The fact that Bakenkhons, who seems to have been descended from a family of priests, was trained as a "stablemaster" does not allow us to call him a "former soldier" as did Kees. ${ }^{26}$ Being acquainted with horsemanship and chariotry may have been a general social necessity of the time, ${ }^{27}$ and high-level priests belonged to the social élite. It is therefore more likely to have been an additional training.

If the period during which Bakenkhons was a cadet coincided with his earliest priestly years, it must be assumed that he entered school at six years of age and was later in the stables of Sethos I as a "cadet" for ten years (until the age of twenty-one); yet, at the same time, between the ages of ten and thirteen or fourteen, he was a $w^{c} b$ priest and afterwards a jtj-ntr for eleven years. If one admits the possibility that he began school later and that (perhaps) there was a certain interval between school and his priestly duties ${ }^{28}$ his education would have ended when he was between twelve and sixteen years of age. The early age for his becoming a priest would not be surprising: apart from the examples from the earlier periods cited above, one may also note the usual practice in Hellenistic Egypt. ${ }^{29} \mathrm{~S}$. Sauneron has pointed out ${ }^{30}$ that, according to a papyrus from Tebtunis, anyone wanting to become a priest had to meet three requirements: he had to be descended from a priestly family, had to be circumcised, and had to be able to read Hieratic. The circumcision should have taken place most probably at the beginning of puberty, ${ }^{31}$ but there are cases where the sons of priests were already registered for circumcision at seven or eleven years of age respectively. ${ }^{32}$ Furthermore, W. Otto cites a fifteen-year-old priest, ${ }^{33}$ and a certain P3-šrj-n-Pth ("III") became high priest of Memphis at the early age of fourteen ${ }^{34}$ after he had spent thirteen years "under the supervision of his father." Before he was appointed high priest, he had doubtless already been initiated as $w^{c} b$-priest. Otto considers whether members of privileged families were perhaps admitted earlier than others to priestly offices. ${ }^{35}$ The same could possibly have been true for the distinguished Bakenkhons family at Thebes.

The career of Bakenkhons thus may have been as follows: he attended school between the ages of six and ten (at most ten to fourteen). Then, extended over a period of seventy years, his service in different priestly offices follows, ${ }^{36}$ and parallel to its beginning (years ten to twenty-one or-at most-fourteen to twenty-five), the period as cadet, i.e., his training in horsemanship and chariotry.

${ }^{26}$ Kees, Priestertum, p. 118.

27 See Lexikon der Ägyptologie, vol. 6 (Wiesbaden, 1986), p. 1130.

28 See n. 36 below.

${ }^{29}$ See generally W. Otto, Priester und Tempel im hellenistischen Ägypten (Leipzig and Berlin, 1905 and 1908), vol. 1, pp. $210 \mathrm{ff}$.

${ }^{30} \mathrm{~S}$. Sauneron, "Les Conditions d'accès à la fonction sacerdotale à l'époque gréco-romaine," BIFAO 61 (1962): 55-57.

${ }^{31}$ Lexikon der Ägyptologie, vol. 1, p. 728. See also Staatliche Museen zu Berlin, Griechische Urkunden, vol. 5 (Berlin, 1934), §91: "Da die Pubertät, die in Ägypten mit 13 oder 14 Jahren anzusetzen ist, das Alter darstellt, in welchem einer Priester wird...."

I thank W. Brashear for this reference.

32 Otto, Priester und Tempel, vol. 2, p. 326.

33 Ibid., vol. 2, p. 327.

${ }^{34}$ Stela London BM 886 (time of Ptolemy X). See E. A. E. Reymond, From the Records of a Priestly Family from Memphis, Ägyptologische Abhandlungen 38 (Wiesbaden, 1981), pp. 142 and 148.

35 Otto, Priester und Tempel, vol. 1, p. 211, n. 5.

36 The formal "ordination," of course, need not necessarily have taken place immediately after his education. On his statue in Cairo Bakenkhons says (KRI, vol. 3, p. 296, 1. 2) that after his education he was trained as a $w^{c} b$-priest "under the hand of his father"; thus there should have been a certain interval between these periods. 
On the basis of the above discussion, the biography of Bakenkhons can no longer be used for the calculation of the minimal length of the reign of Sethos $\mathrm{I},{ }^{37}$ and the basis for the computation of priestly careers in general (as well as the resulting genealogical connections) must be re-evaluated. ${ }^{38}$ We can assume that the age of a priest at the time of his appointment to the different ranks might have been substantially lower than was assumed before.

${ }^{37}$ There is now a larger margin for the transition from Bakenkhons to $R m-r j$ at the end of the reign of Ramses II.

${ }^{38}$ See Bierbrier, Late New Kingdom, p. 3: “ . . . it will be henceforth presumed that it was highly un- likely for anyone at this time to hold a major priesthood under the age of 35 , and this conclusion will be of great importance in any attempt to analyse the ages of the holders of major priesthoods in Ramesside times." 